\title{
Fluorescence tools for studies of membrane protein insertion
}

\author{
A. V. Kyrychenko', A. S. Ladokhin ${ }^{2}$ \\ ${ }^{1}$ V. N. Karazin Kharkiv National University \\ 4, Svobody Ave., Kharkiv, Ukraine, 61077 \\ ${ }^{2}$ Department of Biochemistry and Molecular Biology Kansas University Medical Center \\ Kansas City, KS, USA, 66160-7421 \\ a.v.kyrychenko@karazin.ua
}

The transition of soluble proteins into lipid membranes and their refolding therein is fundamental to numerous physiological and disease processes. In this review, we present the summary of the application of fluorescence spectroscopy for studying posttranslational insertion of membrane proteins into lipid bilayers. Various methods utilizing environment-sensitive probes, FRET, FCS and fluorescent quenching for structural and kinetic characterization of protein-lipid interactions are discussed. We also describe the application of steady-state and time-resolved fluorescence quenching by lipid-attached quenchers to characterize the membrane protein immersion into the lipid bilayer. Finally, we illustrate the use of the entire battery of spectroscopic approaches to characterize structural, kinetic and thermodynamic properties of the $\mathrm{pH}$-triggered insertion/refolding pathway of the diphtheria toxin translocation domain.

Ke y w o r d s: fluorescence spectroscopy, fluorescence correlation spectroscopy, distribution analysis of depth-dependent quenching, annexin, diphtheria toxin, Bcl-xL

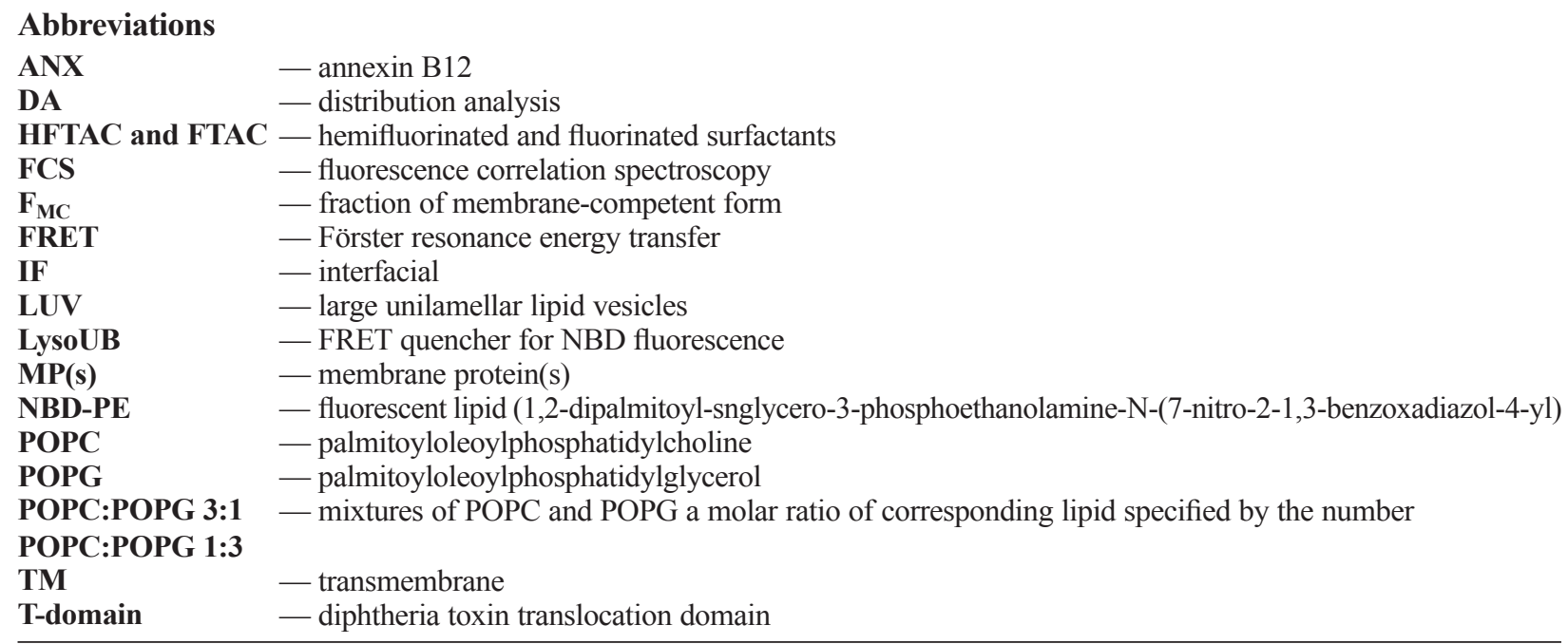

(C) 2018 A. V. Kyrychenko et al.; Published by the Institute of Molecular Biology and Genetics, NAS of Ukraine on behalf of Biopolymers and Cell. This is an Open Access article distributed under the terms of the Creative Commons Attribution License (http://creativecommons.org/licenses/by/4.0/), which permits unrestricted reuse, distribution, and reproduction in any medium, provided the original work is properly cited 


\section{Introduction}

The transition of a soluble protein into a lipid membrane is of fundamental significance in a number of physiological and disease processes. Notable examples include the cellular entry of bacterial toxins, colicins, and viruses, and apoptotic regulation by the $\mathrm{Bcl}-2$ protein family. Proteins of several classes insert into biological membranes in translocon-independent manner after being refolded from the initial water-soluble structures. The unique characteristic of these proteins is their ability to move from the polar environment of the aqueous medium to the non-polar milieu of the lipid bilayer in response to a given cellular/ chemical signal. Figure 1A shows some examples of proteins that refold and insert into membranes in response to the external signal, such as change in $\mathrm{pH}[1,2,3]$, proteolytic cleavage or activation by conformational switching due to the interaction with lipid or protein partners $[1,4,5,6,7,8]$. For instance, the mechanism of action of some bacterial toxins involves the membrane insertion and refolding of specific domains in response to the acidic environment of the endosome [9], which ensures toxin's entry into the cell. [The] Others, such as the apoptotic regulator Bid, are activated by proteolytic cleavage, resulting in partitioning into mitochondrial outer membrane. Other apoptotic regulators of Bcl-2 family, such as Bax and Bcl-xL[,] partition either in $\mathrm{pH}$-dependent manner or after being activated by Bid via the release of hydrophobic anchoring sequences [10]. While in all of the presented examples the soluble structures have been determined by NMR or X-ray crystallography, the structures of the inserted forms or details of the insertion pathway are more challenging to capture.

One of the main reasons for the lack in our understanding of the physiological action of these proteins is the shortage of appropriate experimental tools to study the process of their bilayer insertion. Because the refolding on membrane interface and subsequent transbilayer insertion produce multiple intermediate states (e.g., Fig. 1B), high resolution methods are difficult to apply and structural information is teased out by various types of the fluorescence spectroscopy [9]. In the following sections, we will show how fluorescence-based approaches can be applied to monitor different aspects of protein membrane insertion, including kinetic pathways of membrane insertion and free energy landscapes, specific conformational changes, structure and topology of membrane-inserted states, as well as elucidating the role of lipids on the membrane protein insertion pathways. Additional details on the applications of fluorescence spectroscopy in the membrane protein studies can be found in the following recent reviews, describing thermodynamic measurements of membrane binding [11] and determination of the depth of membrane penetration by proteins and peptides [12].

\section{Methods to monitor partitioning into the membrane}

A critical aspect on monitoring membrane partitioning of proteins is distinguishing the population of protein, which is bound to the membrane, from that free in solution. Classical biochemical techniques, e.g. equilibrium dialysis or size-exchange chromatography, have been used to separate both populations; how- 

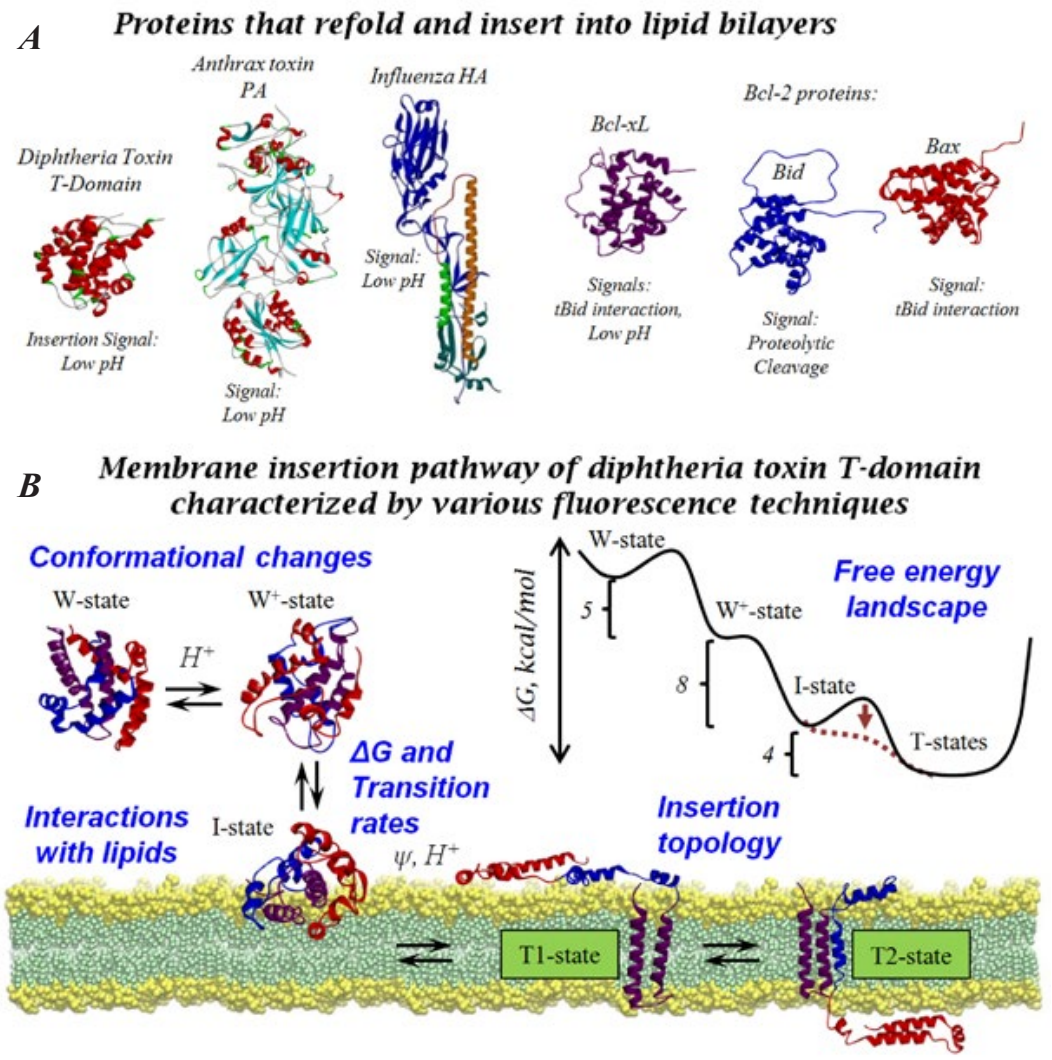

Fig. 1. $A$ - Examples of membrane proteins that refold and insert into the membranes posttranslationally in response to a physiological signal, such as acidification or proteolytic cleavage. $B-\mathrm{pH}$-triggered membrane insertion pathway of the diphtheria toxin T-domain [9], responsible for the cellular entry of the toxin. Various fluorescence applications can be used to study different structural and thermodynamic aspects of the membrane insertion process, including refolding, lipid interactions and bilayer insertion topology $[6,11$, $13,14,15,16,17,18,19,20,21,22$, 23, 24]. These spectroscopic approaches are described in sections 2-4 and their applications to studies of the $\mathrm{T}$ domain are summarized in section 5.1 ever, they require high concentrations of protein, which may lead to aggregation and hinder the analysis. Other techniques, such as surface plasmon resonance and bilayer interferometry, require immobilization of proteins to a matrix, which decreases the degrees of freedom and constrains proteins to interact with membranes in specific orientations. Fluorescence-based approaches circumvent these problems because one records the changes in various fluorescence signals associated with partitioning of fluorescence-labeled protein between aqueous and membranous environments $[11,25]$. Thus, it is not required to physically separate membrane-bound and free-in-solution populations of protein, use high concentrations of protein nor immobilize the protein. It should be pointed out that not all fluorescence parameters (e.g., position of spectral maximum) are suitable for quantitative thermodynamic measurements as they do not scale linearly with the fractions of molecular species [26].

\subsection{Application of environment sensitive fluorescent probes to study membrane insertion}

The use of environment-sensitive probes has been demonstrated to be a simplest fluorescence-based method to monitor partitioning of proteins to the lipid bilayer [27]. Environmentsensitive probes change their fluorescent signature depending on the polarity of its imme- 
diate environment [28]. Specifically, when the probe moves from a polar to a non-polar milieu, e.g. from aqueous to membranous environment, the emission spectrum increases in intensity and the position of maximum emission shifts towards shorter wavelengths (blueshift) $[23,29]$. These changes are associated with longer fluorescence decay in the nonpolar milieu. Thus, following these changes in fluorescence allows monitoring the partitioning of a labeled-protein between the aqueous solution and the lipid bilayer [26]. Some examples of environment-sensitive probes include the natural amino acid tryptophan and the commercially available NBD (derivatives of 7-nitro-2-1,3-benzoxadiazol-4-amine dye) and Bimane (derivative of 3-(bromomethyl)-2,5,6trimethyl- $1 H, 7 H$-pyrazolo[1,2- $a]$ pyrazole-1,7dione dye) [30].

Intrinsic tryptophan fluorescence is a classical tool to monitor membrane partitioning and refolding of membrane-active peptides and proteins $[26,31,32,33]$. An important advantage of tryptophan fluorescence is that it does not require site-selective-labeling, because the amino acid is incorporated as part of the peptide sequence. However, tryptophan fluorescence has some disadvantages because proteins usually have multiple tryptophan residues or the signal-to-noise ratio is often not optimal when proteins have a single tryptophan residue. Additional issues regarding tryptophan fluorescence, such as how to deal with light-scattering effects arising from the presence of vesicles, are discussed elsewhere [26]. These challenges can be bypassed by site-selectively-labeling of the protein with environment-sensitive dyes, such as NBD, BODIPY or Bimane, which can improve the signal-to-noise ratio $[6,34,35,36]$.
Figure 2 shows an example of this approach, where the apoptotic repressor Bcl-xL was selectively-labeled with NBD to monitor the $\mathrm{pH}$-dependent interaction with large unilamellar vesicles (LUV) [6]. Bcl-xL is a protein whose cellular action involves [an] interaction with the mitochondrial outer membrane to prevent apoptosis, but this interaction can be triggered by low $\mathrm{pH}$ in vitro. Figure $2 \mathrm{~A}$ shows the NMR structure of Bcl-xL (left) and highlights the residue $\mathrm{N} 175 \mathrm{C}$ (blue CPK), which was labeled with a thiol-reactive form of NBD (right). Because this residue locates in a region suggested to become lipid-embedded (helices $\alpha 5-\alpha 6$, red), the $\mathrm{pH}$-triggered membrane partitioning of fluorescently-labeled-Bcl-xL is expected to cause changes in the fluorescence signal of NBD. Indeed, Figure 2B shows that acidification caused 7-fold increase of the NBD emission intensity and $10-\mathrm{nm}$ spectral blueshift (red spectrum) in comparison to the sample at reference $\mathrm{pH}$ (black spectrum). These changes were associated with [a] longer fluorescence decay (Fig. 2C, red trace). The transition was reversible because returning to the reference $\mathrm{pH}$ caused the recovery of spectral features (Fig. 2B and 2C, blue). This fluorescence-based experiment demonstrated that the Bcl-xL membrane interactions are reversible, allowing thermodynamic study of the system.

Because these probes sense changes in the polarity of extractingthe immediate environment, the changes in fluorescence can occur by the reasons unrelated to partitioning to the membrane. For example, the increase of emission intensity and spectral blue-shift may result from shielding the probe from the solvent as a result of protein refolding in solution rather than partitioning to the lipid bilayer. Because 

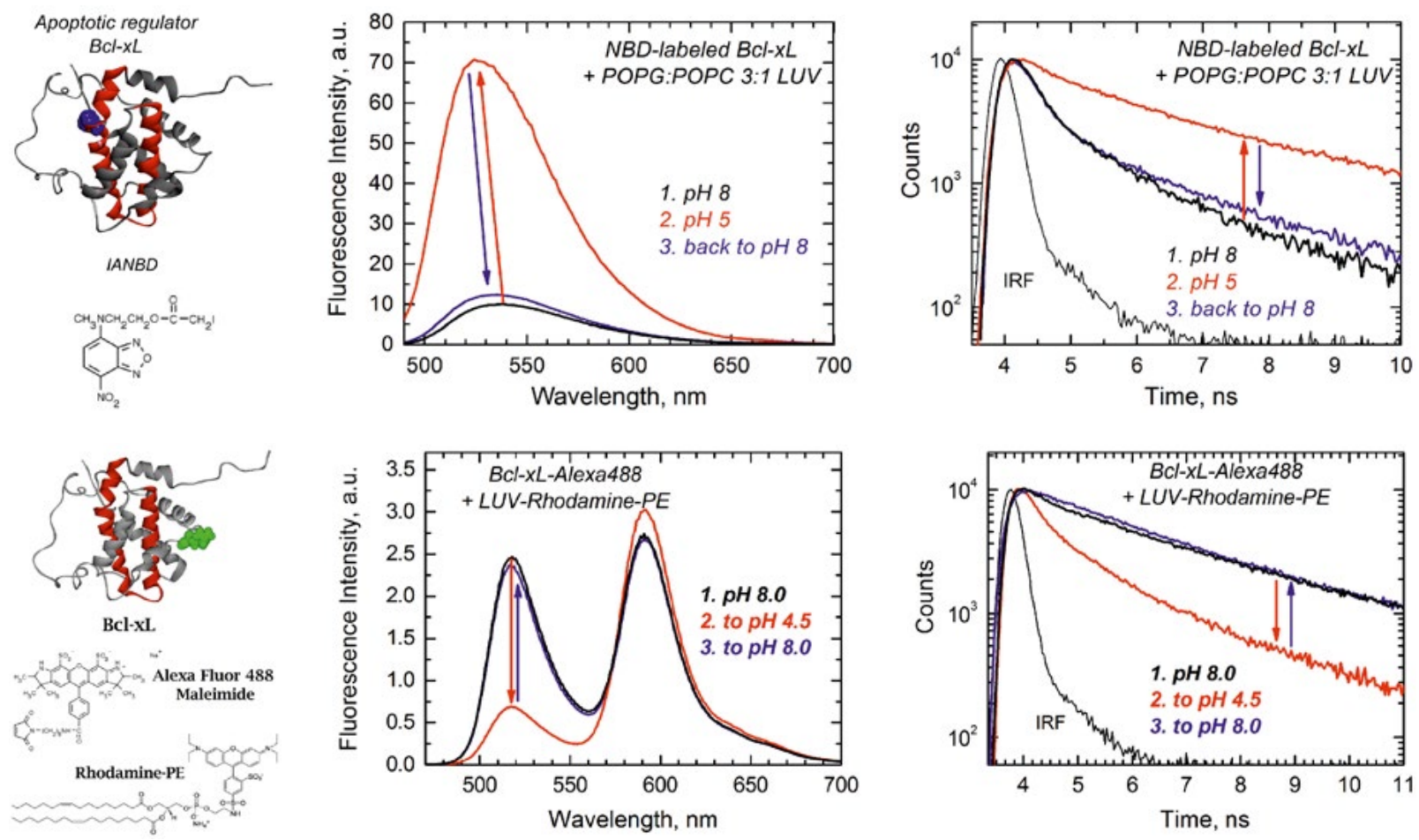

Fig. 2. $A-C-$ NBD-labeling of $\mathrm{Bcl}-\mathrm{xL}$ as a tool to monitor reversibility of protein-membrane interactions. $A-\mathrm{Sche-}$ matic representation of the NMR-based structure of apoptotic repressor Bcl-xL in solution, highlighting putative membrane insertion unit in red and NBD-labeling site in blue CPK. Chemical structure of NBD in a thiol-reactive form. $B$ - Steady-state emission spectra of a premixed solution containing NBD-labeled Bcl-xL and LUV under different $\mathrm{pH}$ conditions. $C$ - Time-resolved emission traces of the same samples in Panel B. Increase in emission intensity, spectral blue-shift and longer fluorescence decay indicate partitioning to the membrane. The results demonstrate reversibility of the $\mathrm{pH}$-dependent association of Bcl-xL with membranes. $D-F-$ FRET-based assay as a tool to monitor reversibility of protein-membrane interactions. $D$ - Structure of Bcl-xL in solution, highlighting putative membrane insertion unit in red and labeling site for donor dye attachment in green CPK. Chemical structures of thiolreactive donor, and acceptor-labeled phospholipid are shown. $E$ - Steady-state emission spectra of a premixed solution containing Bcl-xL and LUV labeled with donor/acceptor pair under different $\mathrm{pH}$ conditions. $F$ - Time-resolved emission traces of the same samples in Panel B. Decrease in emission intensity and shortening of life-time indicate FRET between donor and acceptor. Results demonstrate reversibility of the $\mathrm{pH}$-dependent association of Bcl-xL with membranes. Adapted from Refs. [6, 37].

this may mislead the researcher, one has to complete control experiments in the absence of lipid vesicles and confirm partitioning to the membrane with additional techniques (discussed below). Nonetheless, this property of environment-sensitive probes can be exploited to study conformational changes occurring in solution or in the membrane. For example, tryptophan fluorescence has served to determine the role of histidine protonation in triggering conformational changes of diphtheria toxin translocation domain in solution and in 
the membrane $[23,38,39]$, whereas bimane fluorescence has been used to validate the structures of kinetic intermediates modelled through computational methods [20].

\subsection{FRET-based membrane binding assay}

Förster resonance energy transfer (FRET) is a common strategy to detect binding between two fluorescence-labeled particles [40]. In contrast to the use of environment-sensitive probes (discussed above), this approach does not require the probe to become embedded into the lipid bilayer to yield a fluorescence response. Instead, there is a change in signal that can be experimentally monitored because a donor probe transfers energy to an acceptor probe when they are within the Förster's distance [6, 16]. The experiment consists in site-selectivelabeling the protein and membrane with the donor/acceptor pair, so that the partitioning of the protein causes FRET between the probes.

Figure 2D-F displays a FRET-based experiment applied to the case of the $\mathrm{pH}$-dependent membrane partitioning of Bcl-xL. Figure 2D shows the NMR structure of Bcl-xL, with the labeling site previously mutated to cysteine (green CPK); and chemical structures of the donor AlexaFluor-488 as a thiol-reactive probe, and the lipid-attached acceptor (Rhodamine-PE [30]) dye, which was incorporated to the membrane during vesicle preparation at $2 \%$ molar fraction of total lipid. Figures $2 \mathrm{E}$ and $2 \mathrm{~F}$ show the representative results of this type of experiment, where the FRET-based assay was used to confirm the reversibility of the $\mathrm{pH}$-dependent association of Bcl-xL to anionic membranes. Acidification of the sample containing premixed labeled $\mathrm{Bcl}-\mathrm{xL}$ and labeled vesicles caused a decrease in emission intensity of the donor (Fig. 2E, Steps 1 and 2) and a shortening of the fluorescence life-time of the donor (Fig. 2F, Steps 1 and 2). Returning to the reference $\mathrm{pH}$ caused the recovery of the initial spectral features (Fig. 2E-F, Step 3). Together, the data indicate that $(i)$ there is FRET between the donor/acceptor pair, which occurs under acidic conditions; and (ii) FRET vanishes when reversing the $\mathrm{pH}$ conditions. These observations are consistent with a population of labeled Bcl-xL partitioning to the labeled lipid bilayer in a $\mathrm{pH}$-dependent and reversible manner.

\subsection{FCS-based methods to quantify membrane interactions in the presence of membrane-competent and incompe- tent protein conformations}

FCS technique has been successfully used to study interfacial binding of peptides and proteins $[41,42]$, as well as to study transmembrane insertion of proteins [11, 41, 42, 43, 44]. In recent years, several excellent reviews have been published within this topic $[45,46]$, focusing on the rapid development and applications of FCS for in cell studies. Additionally, the technical aspects of the FCS method have been intensively reviewed elsewhere $[47,48]$. The formalism of FCS analysis for a general case of complex binding equilibrium was typical for $\mathrm{pH}$-dependent binding of membrane proteins $[11,37]$.

\section{Fluorescence and structural studies of MPs}

\subsection{Determination of interfacial and transmembrane topology of MPS}

Determination of the topology of a particular site on a membrane protein (i.e., its position 
with respect to the two leaflets of the lipid bilayer) is an important step in elucidating its structure. And even if the structure of a membrane protein is known, topology measurements are useful for verifying its correct fold and orientation after reconstitution into model membrane systems [49]. Measurements of topology have been especially important in the determination of membrane insertion pathways for a variety of spontaneously inserting nonconstitutive proteins, such as bacterial toxins $[9,50,51]$, colicins $[52,53]$, some annexins $[44,54]$ and numerous apoptotic regulators of the Bcl-2 family $[5,6,7,8,10]$.

The topology of the membrane protein can be determined by combining site-selective labeling of the protein with a fluorescent probe, and symmetric and asymmetric labeling of the membrane with a quencher $[29,55,56,57$, 58]. The idea is that the topology of the membrane protein can be deduced by comparing the fluorescent response of the fluorophore upon the interaction of the labeled-protein with symmetric- or asymmetric-labeled membranes. Examples of these quenchers include LysoMC, a methylcoumarin derivative capable of quenching tryptophan fluorescence [57, 58]; and LysoUB (Fig. 3A), a UniBlue chromophore derivative capable of quenching NBD fluorescence $[59,60]$. In both cases, the quenching occurs through non-radiative Förster type energy transfer (FRET). Because singlechain lyso-lipids have significant water solubility and form micelles, they can be incorporated easily into the outer leaflet when added to preformed bilayer vesicles. The bulky charged quencher headgroup and single-acyl chain act in concert to slow lipid flip-flop, resulting in asymmetric distribution, which is stable for the topology measurements under equilibrium conditions.

While LysoMC has been useful for determining the topology of relatively short tryptophan-containing peptides $[57,58]$, several problems arise when it is applied to proteins (e.g. weak tryptophan fluorescence, poor spectral selectivity, parasitic LysoMC fluorescence). These problems can be bypassed by using LysoUB as quencher of NBD fluorescence [59]. Another advantage of LysoUB is that the Förster radius from NBD to LysoUB, which ranges from 30 to $35 \AA$ depending on the donor's quantum yield and spectral position, is about the same as the thickness of the bilayer hydrocarbon core. Thus, the FRET efficiency will be the highest when the quencher and fluorophore are in the same leaflet and the lowest when they are separated by the bilayer. This can be measured by monitoring changes in donor intensity or lifetime [60], where the latter is preferred because it is less susceptible to artifacts associated with partial loss of sample.

In the example shown in Figure 3, quenching of NBD by LysoUB-labeled membranes was used to determine the topology of annexin B12 (ANX) in the lipid bilayer. Because LysoUB quenching is stronger for NBD located in the same leaflet, the quenching is different for the two hypothetical cases shown in the figure (Fig. $3 \mathrm{~B}, \mathrm{C}$ and $\mathrm{D})$. The ratio of the longest decay time $[\mathrm{s}]$ in the absence and presence of $2 \%$ LysoUB was used to assign the topology of the NBD-labeled site [44]. The results indicate that residue 134 remains on the cis side at all times, whereas residue 162 is rapidly translocated in LUV with low content of anionic lipids (POPC:POPG 3:1). The use of LUV with an 
$\boldsymbol{A}$

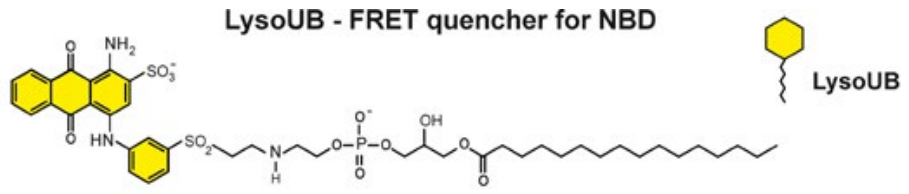

B

Insertion Topology of D-E Helix of Annexin B12

$A N X-134-N B D$

... D134C(NBD)-LEKEIISETSGNFQRLLVSMLQGGRKED ...

$A N X-162-N B D$

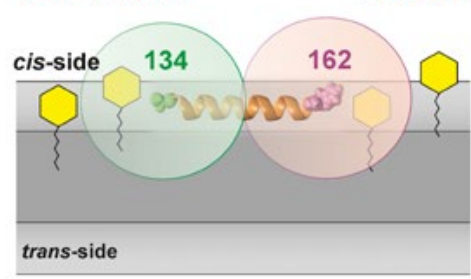

IF $\alpha$-helix

(10-min incubation of ANX with LUV prior to addition of lysoUB)

C

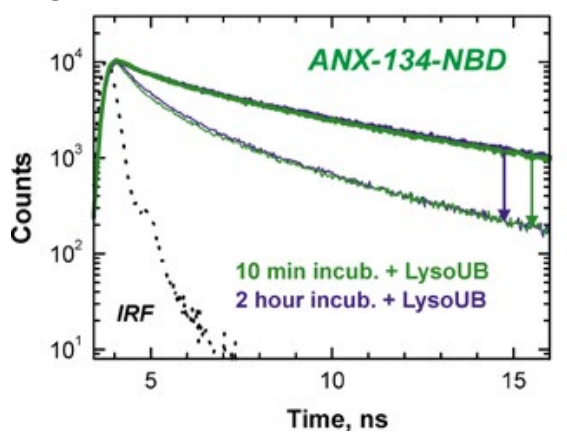

Fig. 3. $A-$ Chemical structure of LysoUB, a compound comprised of

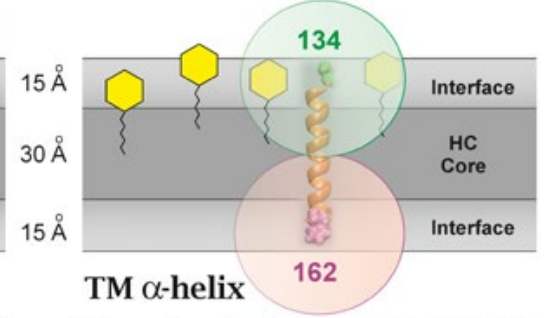

(2-hour incubation of $A N X$ with LUV prior to addition of lysoUB)

\section{D}

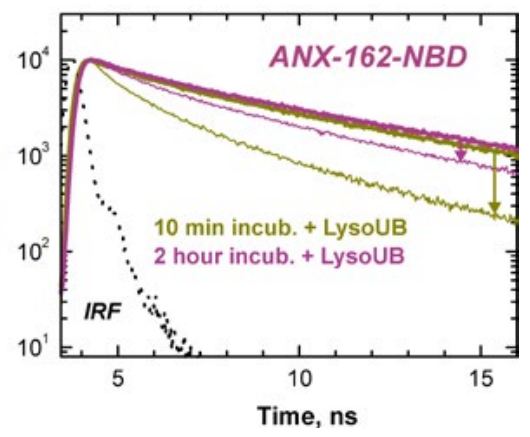

UniBlue chromophore attached to a lyso-lipid. $B-$ Schematic represen- tation of application of LysoUB/ NBD quenching method to study insertion pathway of annexin B-12 (ANX). To study the topology of the D-E helical region (residues 134162), the following two single-Cys mutants were labeled with NBD fluorophore at positions at either side of the helix: ANX D134C and ANX D162C. Shaded circles illustrate the range of efficient quenching from an NBD-labeling site. $C-D$ - Lifetime experimental scheme for determining membrane topology of the NBDlabeled protein. Typical fluorescence decay experiment used to determine the topology of the NBD probe attached to ANX residue 162. $C$ - or residue 134. $D-$ in POPC:POPG 1:3 LUV. Arrows illustrate the amount of quenching caused by addition of $2 \%$ LysoUB after $10 \mathrm{~min}$ or $2 \mathrm{~h}$ of the initiation of protein insertion. Strong quenching indicates the cis location of the probe (e.g., ANX-134-NBD or ANX-162-NBD after 10 min incubation with POPC:POPG 1:3 LUV). Translocation of the protein-attached NBD across the bilayer results in reduced quenching (e.g., ANX-162-NBD after $2 \mathrm{~h}$ incubation). increased content of anionic lipids hinders the translocation by stabilizing the interfacial kinetic intermediate presumably via electrostatic attraction of lipid headgroups and R149, located in the middle of the segment $[44,59]$.

\subsection{Depth-dependent fluorescence quenching by lipid-attached quenchers}

Accurate determination of the penetration depth of proteins and peptides into lipid bilay- ers is an important step in studying the binding, topology and folding of membrane proteins. However, extracting of quantitative information from fluorescence studies about the membrane location of an intrinsic fluorophore or a site-selectively attached external probe is typically complicated by broad distributions of the transverse positions of both quenchers and fluorophores. Therefore, depth-dependent fluorescence quenching with a series of lipid- 
attached quenchers, such as bromine atoms or paramagnetic Tempo and Doxyl groups (Fig. 4A), has become an important spectroscopic tool for the calculating of a precise depth of a fluorescent moiety [12, 61, 62, 63]. While bromolipids can be utilized as quenchers for tryptophan and pyrene fluorescence, the lipid-attached spin moieties, in addition to those, can also quench other organic fluorophores, including NBD, rhodamine, bimane and antracene. The transverse position of bromine atoms has been determined by X-ray diffraction [64], whereas the position of spin labels has been recently refined by MD simulations [65].

The main assumption of the depth-dependent quenching methodology is that the quenching between a fluorescence dye and a quencher will be greatest when they are located at the same depth within the bilayer. To quantitate the membrane penetration the quenching profiles are measured and fitted using Distribution Analysis (DA) method [12, 61]. DA reconstructs a depth-dependent quenching profile by using the quenching data collected from a series of quenchers, located

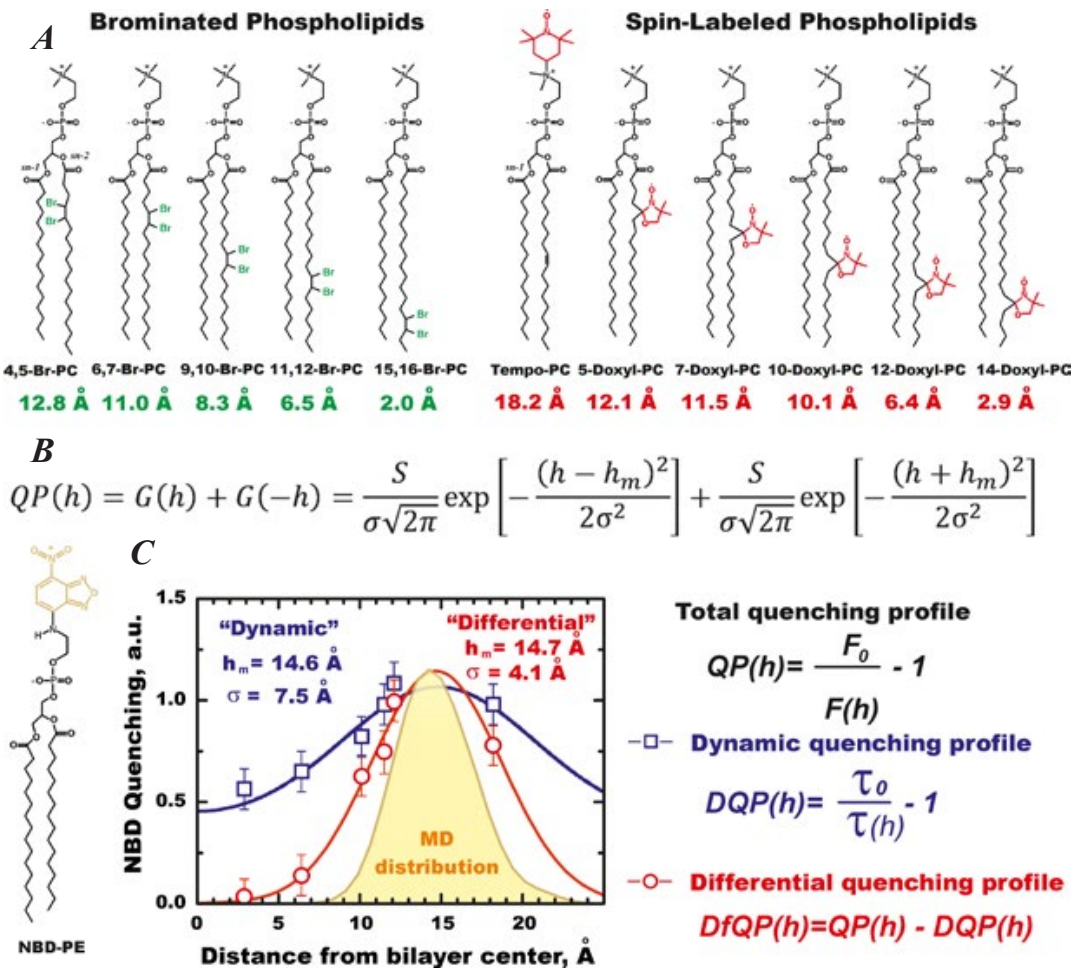

Fig. 4. A-Lipid-attached fluorescence quenchers used for depth-dependent measurements and their depth (the distances from bilayer center to the quencher) $[64,65]$. Brominated phospholipids: 1-palmitoyl2-(n,n-dibromo)stearoyl-sn-glycero3-phosphocholine $\quad(n, n$-Br-PC).
Spin-Labeled phospholipids: 1-palmitoyl-2-oleoyl-sn-glycero3-phospho(TEMPO)choline (Tempo-PC), 1-palmitoyl-2-stearoyl- $(n-$ doxyl)-sn-glycero-3-phosphocholine (n-doxyl-PC). $B-$ The DA methodology approximates the transverse quenching profile $(Q P(h))$ with a sum of two mirror-image Gaussian functions $(G(h))$, where $h_{\mathrm{m}}$ - the center (mean) of the quenching profile, $\sigma$ - the width of the distribution, and $S$ - the area of the quenching profile $[12,61,62,63] . C-$ Structure of NBD-PE (1,2-dipalmitoyl-sn-glycero-3-phosphoethanolamine-N-(7-nitro-2-1,3-benzoxadiazol-4-yl)). Depth-dependent profiles of NBD-PE quenched by the spinlabeled lipids plotted for lifetime quenching (squares) and "differential" quenching (circles) calculated as the difference between total and dynamic quenching. The MD-simulated depth probability profile of the NBD moiety (yellow area) is shown for comparison. 
at the known depths ( $h$ ) within the membrane (Fig. 4). The DA methodology approximates the transverse quenching profile (QP) of a fluorophore with a symmetrical twin Gaussian function (Fig. 4B), which has three fitting parameters: $h_{\mathrm{m}}=$ the center (mean) of the quenching profile, $\sigma=$ the width of the distribution, and $S=$ the area of the quenching profile. These parameters correspond to the most probable depth of penetration, fluctuations in the transverse position, and overall accessibility to quenching (i.e., quenching efficiency), respectively [62]. Unlike in the previously described LysoUB quenching method (Section 3.1), the quenchers are distributed in both leaflets. In order to account for possible trans-leaflet quenching of deeply penetrating fluorophores, the mirror-image G(- $h$ ) component is added to the main Gaussian component $\mathrm{G}(h)$ [62].

The accuracy of membrane depth calculations is still crucially dependent on the precise positioning of the lipid-attached spin-quenchers within the bilayer. Therefore, the average positions of the spin quencher calculated from the center of the lipid bilayer have recently been determined by MD simulations of a series of spin-labeled lipids in the model membrane [65]. A combination of molecular dynamics (MD) simulations and depth-dependent fluorescence quenching was used to calibrate the methodology for extracting quantitative information on the membrane penetration of fluorescent-labeled molecules [66].

In the model system NBD-PE, the NBD moiety attached to the lipid headgroup (Fig. 4C) was studied in a POPC bilayer. The immersion depth of NBD was estimated by measuring steady-state and time-resolved flu- orescence quenching with six different spinlabeled lipids co-incorporated into lipid vesicles (Fig. 4C). The overall width of the quenching profile, which is determined by physical sizes of the fluorophore and quencher, and widths of their thermal envelopes are quite large (Fig. 4C, squares). The differential quenching profile $D f Q P(h)$ (Fig. $4 \mathrm{C}$, circles) can be calculated as the difference between the total quenching efficiency and the dynamic component, defined as a quenching efficiency observed in a lifetime quenching experiment $[67,68]$. Fig. 5C shows that although the average depth position estimated by both methods is the same, the differential quenching profile is much narrower than the dynamic profile. Using the methodology of DA, the immersion depth from the bilayer center to the NBD moiety was estimated to be $14.7 \AA$, which was independently validated by using atomistic MD simulations of NBD-PE lipids in a POPC (14.4 ̊̊) [66, 67].

\section{Application of fluorescence tech- niques to characterize membrane interactions of the diphtheria toxin $T$ domain}

In this section, we summarize the applications of all above fluorescence techniques to study various aspects of membrane interactions of the T-domain. A simplified scheme for this interaction pathway is shown in Figure 1B, where we illustrate the three major steps under study. Step 1 occurs in solution and comprises the transition from the $\mathrm{W}$-state to the $\mathrm{W}^{+}$-state. The several independent fluorescence-based binding assays, including FRET, FCS, and site-selective labeling of the protein with environment-sensitive probe, were utilized to 
examine this conformation transition and the membrane interaction of the T-domain at low $\mathrm{pH}$. Step 2 corresponds to the partitioning of the $\mathrm{W}^{+}$-state to the membrane interface to form the interfacial I-state (Fig. 1B). The kinetic pathway for the membrane insertion of the T-domain is considered revealing a series of conformational changes that occur in solution and in the membrane. For the partitioning to the membrane interface and the TM insertion we used FCS-based methodology. Finally, step 3 refers to a series of conformational rearrangements that switch the I-state into the final and functional transmembrane T-state. The membrane topology of this state is characterized by the LysoUB quenching method.

\section{$4.1 \mathrm{pH}$-Dependent formation of mem- brane-competent state of the T-domain}

Formation of the membrane-competent form $\left(\mathrm{W}^{+}\right.$-state) of the T-domain is the first step along a complex pathway, leading from a soluble conformation with a known crystallographic structure [69] (W-state) ultimately to the membrane-inserted states (Fig. 1B) $[9,14$, $16,17,24]$. Protonation of T-domain histidine side-chains has been recognized to play an important role in various stages of the membrane insertion process, so that $\mathrm{H} 257$ and $\mathrm{H} 223$ were implicated to act as a molecular switch that triggers disruption of the native structure of W-state of T-domain in low $\mathrm{pH}$ solution [9, $17,18,20]$. The $\mathrm{pH}$ dependent conformational transition $\mathrm{W}$-to- $\mathrm{W}^{+}$is normally identified in a membrane-binding assay conducted under conditions of LUV saturation [9, 24]. The application of three independent fluorescence methods for the membrane binding to the T-domain's interaction with LUV is summa- rized in Figure 5A-B: $(i)$ diffusion measurements by FCS technique (Fig. 5B, diamonds), (ii) association of donor-labeled T-domain and acceptor-labeled vesicles by FRET (Fig. 6, circles) [16], and (iii) changes in polarity of a specifically attached environment-sensitive bimane probe by [an] increase in the fluorescence intensity (Fig. 6, triangles) [20].

The obtained $\mathrm{pH}$ dependencies of $F_{\mathrm{MC}}$ were fitted to the $\mathrm{Eq}(1)$.

$$
F_{M C}=\frac{1}{1+10^{n(p H-p K a)}}
$$

where $p K_{\mathrm{a}}$ is a negative logarithm of the dissociation constant and $n$ is the Hill coefficient.

All combined datasets were fitted with the Eq. 1 and could be adequately described by a single fitting curve with a $p K_{\mathrm{a}}$ of 6.2 and a Hill coefficient of about 2 (Fig. 5B, line). Thus, these measurements confirmed that $\mathrm{W}^{+}$-state is an experimentally observable state of the protein with a conformation different from that of the $\mathrm{W}$-state. The structure and the dynamics of $\mathrm{pH}$-dependent conformation switching of the T-domain have been a subject of MD simulations reported elsewhere [20, 22, 23, 70].

\subsection{Lipid-dependent modulation of the kinetics of membrane association and insertion of TH8-9 helical hairpin of the T-domain}

To test the insertion topology of the diphtheria toxin T-domain, the NBD probe was attached to the very tip of the insertion domain formed by helices TH8 and TH9 using the L350C mutant (Fig. 5A) [16]. If these helices adopt the TM conformation upon insertion, the 

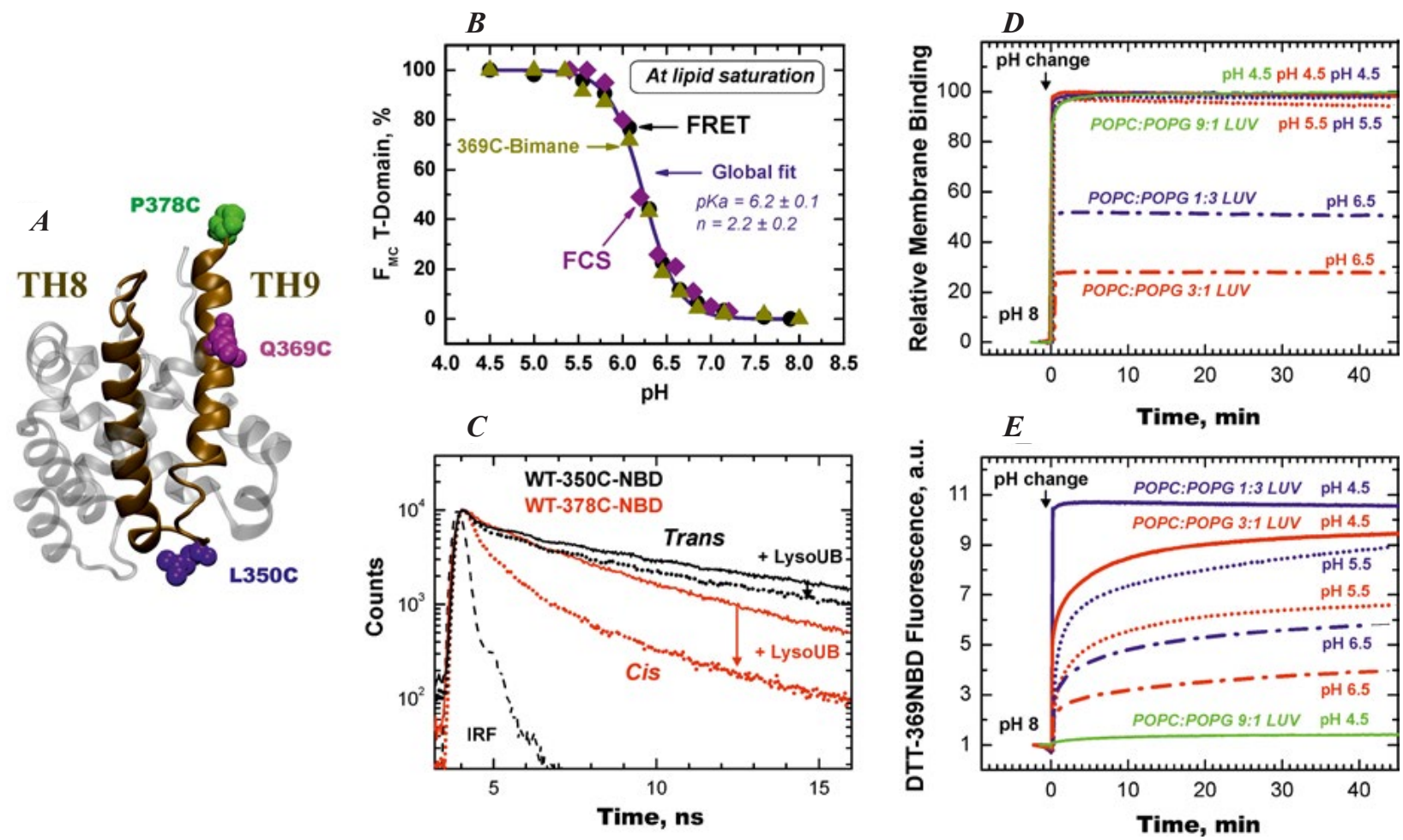

Fig. 5. $A$ - Crystallographic structure of the diphtheria toxin T-domain in soluble form at neutral $\mathrm{pH}$ [69]. The consensus insertion hairpin consisting of helices TH8 and TH9 is shown solid, while the rest of the structure is shown semitransparent. Three residues, L350, Q369, and P378 (highlighted in CPK), along TH9 were replaced with cysteines (one at a time), providing unique labeling sites for fluorescence dye NBD used in steady-state and kinetic measurements of insertion. $B-\mathrm{pH}$-dependent conversion of the T-domain from the soluble $\mathrm{W}$-state into the membranecompetent $\mathrm{W}^{+}$-state. Identification of $\mathrm{W}$-to- $\mathrm{W}+$ transition through membrane binding at lipid saturation. Mobility measurements based on FCS (diamonds) and measurements of FRET between donor-labeled T-domain and acceptorlabeled LUVs (circles) were performed as described in [16]. Triangles represent the increase in fluorescence intensity of environment-sensitive probe bimane attached to a single cysteine in position 369 (A). Modified from Ref. [20]. $C$ - Application of the Lyso-UB quenching to determine the topology of TH9 in POPC:POPG 1:3 LUV. The difference in quenching of NBD attached at position 350 (black) and 378 (red) indicates TM insertion of the hairpin and translocation of the loop between the TH8 and 9 (Note that this segment remains in the IF orientation when T-domain binds LUV with low content of anionic lipids [16]). $D-E-$ Membrane binding and insertion kinetics of the T-domain measured with LUV of specified lipid compositions (color-coded) at various $\mathrm{pH}$ (line coded). $D$ - Binding kinetics was followed by the change in FRET signal between donor-labeled T-domain and acceptor-labeled LUV. E - Insertion kinetics was followed by changes in fluorescence intensity of environment-sensitive probe NBD attached to the center region of the membrane-insertion domain (Q369C-NBD). Differences observed in the two types of kinetics reveal the insertion intermediate, which depends on $\mathrm{pH}$ and lipid composition. Modified from Ref. [16].

probe will be translocated across the bilayer and become inaccessible to the externally added LysoUB quencher. If the helices remain interfacial, the quenching will be substantial. [The] LysoUB quenching experiments were performed after the T-domain insertion had 
come to equilibrium in 1 hour after mixing the T-domain and LUV at low $\mathrm{pH}$. In order to describe LysoUB quenching, and the resulting topology, in a quantitative way, the fluorescence decay for all samples was analyzed and the ratio of the average lifetime upon addition of the quencher has been calculated, as described previously [60]. We found that the degree of quenching depends on the lipid composition. The lifetime ratio $\tau_{\alpha} / \tau_{0}$ of about 1.1 observed in POPC:POPG 3:1 and POPC:POPG $1: 3$ is indicative of efficient translocation, whereas the ratio $\tau_{\alpha} / \tau_{0}$ of 1.7 observed in POPC:POPG 9:1 confirms interfacial topology. In fact, the same quenching ratio was observed in a control experiment using the NBD-labeled P378C mutant, for which no translocation is expected during TH8-TH9 insertion (Fig. 5A).

Formation of intermediates and subsequent transbilayer insertion are mediated by a subtle balance of hydrophobic and electrostatic interactions between proteins and the membrane interface. The applications of fluorescence spectroscopy for kinetic measurements of the T-domain insertion along the pathway from aqueous $\mathrm{W}$-state to interfacial intermediate I-state and finally to transbilayer inserted T-state are summarized in Fig. 5D and E. To study time-dependent association with the membrane, the kinetic measurements using the FRET signal between AlexaFluor488labeled T-domain and Rhodamine- labeled LUV were used. The validity of this FRET approach was verified by comparing equilibrium titration profiles with those obtained by FCS (Fig. 5B, circles and diamonds). Additionally, FRET-based binding kinetics (Fig. 5D) was compared to those observed with the environmentally sensitive probe NBD attached to a single-Cys residue in the Q369C mutant of the T-domain (Fig. 5A and E). This residue is relatively solvent-exposed in the soluble T-domain at neutral $\mathrm{pH}$ (W-state) and according to our topology result (Fig. 5C) is in the middle of the TM segment in the inserted T-state. Such a transition is expected to result in a substantial increase of the fluorescence of NBD, which was indeed observed, as shown by the kinetics measurements in Fig. 5E. In contrast to the fast FRET-based binding kinetics, the fluorescence kinetics of NBD was slow and dependent on the lipid composition. This indicates that there is a membrane-bound, but not fully inserted, kinetic intermediate (I-state) that can be kinetically trapped. Remarkably, the insertion kinetics demonstrated that I-to-T transition is already occurring at $\mathrm{pH} 6.5$, at which point the binding W-to-I transition is only half completed (dashed-dotted lines in Fig. 5E) [16]. These results suggest that the protonation transitions allowing membrane binding and TM insertion are staggered, which could be related to an additional protonation of the T-domain on the interface due to variations in $\mathrm{pK}_{\mathrm{a}}$ in bulk of solvent and the membrane interfacial zone.

\subsection{Determination of the depth of mem-} brane penetration of NBD-labeled mutants of the diphtheria toxin T-domain

We illustrate the application of the DA methodology by examining steady-state and timeresolved depth-dependent quenching for the two limiting cases of shallow (P378C-NBD) and deep penetration of the probe (A282CNBD) in Fig. 6. Panels 6A and 6C show the primary experimental data for steady-state intensity (triangles) and lifetime quenching 

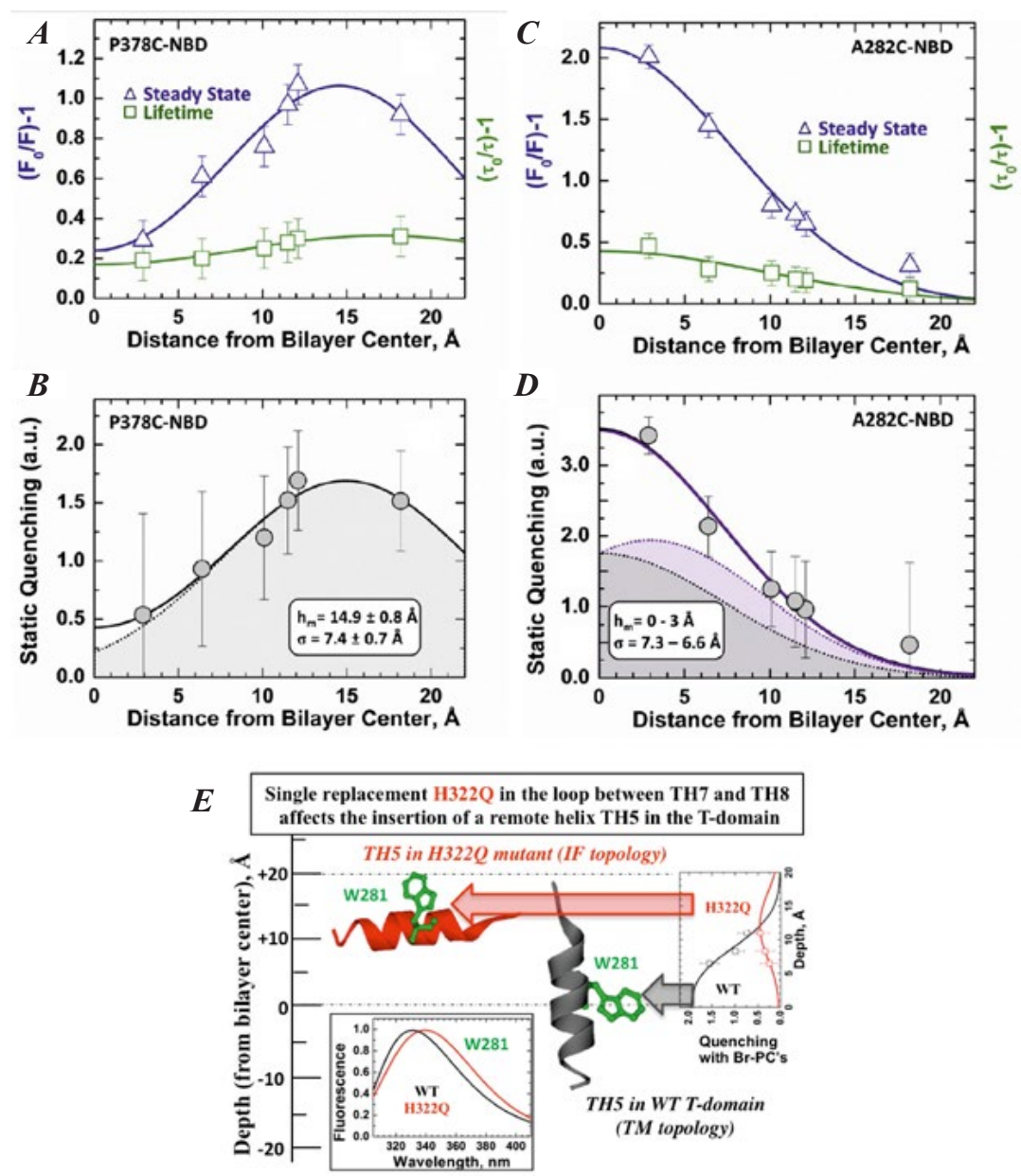

Fig. 6. Application of distribution analysis (DA) to depth-dependent fluorescence quenching of shallow and deep penetrating probe in P378C-NBD and A282C-NBD mu- tants of diphtheria toxin T-domain, respectively. (A and $\mathbf{C}$ ) Fluorescence steady-state (triangles) and time-resolved (squares) quenching profiles plotted against the depth of the following quenchers (from right to left): Tempo-PC and $n$-DoxylPCs with $n=5,7,10,12$, and 14. (B and D) Static $\mathrm{QP}(h)=\left(F_{0} / \mathrm{F}(h)\right) /$ $\left(\tau(h) / \tau_{0}\right)$. Solid lines represent the fit of the corresponding datasets using the DA equation (Fig. 4B). The shaded areas represent a Gaussian function for the single leaflet quenching profiles. The sum of the shaded area, $\mathrm{G}(h)$, and its mirror image, $\mathrm{G}(-h)$, represents the total fitting function of DA, with the total of three fitting parameters: $h m, \sigma$, and $S$. (D) Solid shapes represent two examples of individual solutions for a single-leaflet quenching profile $(\mathrm{G}(h)$ in the DA equation in Fig. 4B) with $h m=0$ A (gray) and $h m=3 \mathrm{~A}$ (purple). Both solutions produce essentially overlapping two-leaflet quenching profiles, defined in the DA equation in Fig. 4B as a sum of $\mathrm{G}(h)$ and its mirror image, $\mathrm{G}(-h)$. (E) A single replacement of $\mathrm{H} 322$ results in repositioning of the TH5 helix from TM state (WT, black) to IF state (H322Q mutant, red), associated with loss of channel-forming activity $[18,21]$. This repositioning can be followed by changes in spectral position of W281 (lower panel) and its quenching with brominated lipids (right panel) [71]. (squares). Data in panels B and D are derived from the primary data and represent static $\mathrm{QP}(h)=\left(F_{0} / \mathrm{F}(h)\right) /\left(\tau(h) / \tau_{0}\right)$. The colored profiles in panels $\mathrm{B}$ and $\mathrm{D}$ represent individual Gaussian functions, $\mathrm{G}(h)$, whereas the total QP's are a sum of $\mathrm{G}(h)$ and its mirror image $\mathrm{G}(-h)$, accounting for the transleaflet quench- ing. The latter is more pronounced for the deeply penetrating probe in case of $\mathrm{A} 282 \mathrm{C}$ NBD (Fig. 6D).

Fig. 6A-B shows that for a shallow penetrating fluorophore P378C-NBD, the steady-state and differential QPs produce similar results, suggesting that the most probable location of 
the probe is between 14 and $6 \AA$ from bilayer center. The lifetime QP is less well defined and suggests the highest dynamic component to quenching of fluorophores with the depth ranging from 16 to $19 \AA$. In contrast, the position of deeply penetrating fluorophore, A282C$\mathrm{NBD}$, is less defined, primarily due to the uncertainty introduced by a cross-leaflet quenching. As the result, the distributions centered at 0 or $3 \AA$ produce practically the same overall fit (solid lines in the same panels). Regardless of somewhat higher uncertainty, these data suggest that the residue A282, positioned in the middle of TH5, is located in the center of the bilayer. Attaching probes in the middle of TH5 results in deep quenching profiles, consistent with the transmembrane insertion of this helix.

The information provided by the depthdependent fluorescence quenching of membrane inserted T-domain of diphtheria toxin was used to set the initial configuration for the molecular dynamics computer simulations as described by Kyrychenko and co-workers [68]. The combined application of experimental and computational techniques resulted in construction of an atomistic model of the protein-lipid complex, which provided both mechanistic and thermodynamic insights into functioning of the T-domain [68].

\subsection{Bilayer positioning of TH5 helix in WT and H223Q mutant of diphtheria} toxin T-domain using intrinsic fluorescence

Recent results indicate that $\mathrm{H} 322$ is critical for proper insertion of the $\mathrm{N}$-terminal part of the T-domain and formation of the so-called OpenChannel State $[18,21]$. Replacements with Q,
$\mathrm{R}$ or $\mathrm{K}$, while not affecting folding in solution or proper insertion of TH8-9, lead to misfolding of the remaining structure on the membrane interface. This lack of proper insertion can be monitored by red-shifted tryptophan fluorescence, associated with changes in insertion of W281 located in TH5. The spectroscopic changes become even more pronounced in a single-Trp mutant W206F (Fig. 6E [37]). This variation in the insertion mode is confirmed by the results on an independent depthdependent quenching experiments using three commercially available bromolipids with differed depth, $h$ : 6-7BrPC ( $h=11 \AA$ ), 9-10BrPC $(h=8.3 \AA)$ and 11-12BrPC ( $h=6.5 \AA)$ (Fig. 4A). Each of the bromolipids was mixed with anionic POPG in 1:1 molar ratio. The intensity of tryptophan fluorescence of the T-domain was measured in the presence of quenching vesicles, $F(h)$ and in quencher-free POPCPOPG LUV, $F_{0}$. The "total" quenching profile was generated as $Q P(h)=F_{0} / F(h)-1$ and analyzed using DA method $[12,61]$ by fitting to the twin Gaussian function (equation in Fig. 4B-C). Because the quenching profile for the mutant was poorly defined, the dispersion parameter s representing the width of the distribution was fixed at 5, 6 or $7 \AA$. Regardless of the chosen value, the results indicate that W281 in the WT is located close to the center of the lipid bilayer and remains close to the interface in H223Q mutant (Fig. 6E). Both spectroscopic experiments presented in Fig. $6 \mathrm{E}$ support the hypothesis that $\mathrm{H} 223 \mathrm{Q}$ mutant is trapped in T1-state and does not form a fully-inserted T2-state with a translocated $\mathrm{N}$-terminus (Fig. 1B) [18, 21]. While the exact mechanism of how the replacement of H322 influences the topology of the segment some 
40 residues away remains a mystery, the result confirms that fluorescence measurements constitute an important tool for studies of membrane protein folding. Remarkably, the channel-blocking replacement of H322 in the T-domain does not affect the toxic potency of the protein, suggesting that the so-called OpenChannel State is not a productive intermediate, but a byproduct of the translocation of the catalytic moiety of the toxin across the endosomal membrane [71].

\section{Perspectives}

Dynamic disorder of the lipid bilayer presents a challenge for establishing structure-function relationships in membraneous systems. The resulting structural heterogeneity is especially evident for peripheral or spontaneously inserting membrane proteins, which are not constrained by the transmembrane topology and exert their action in the context of intimate interaction with lipids. This heterogeneity substantially impairs the application of such traditional high-resolution structural methods as NMR, X-ray crystallography and electron microscopy. As a result, fluorescence spectroscopy becomes an increasingly important tool for studies of insertion of proteins into lipid bilayers. As demonstrated in this review, various fluorescence approaches can be applied to obtain critical structural and thermodynamic information enabling the deciphering of complex insertion/refolding pathways. It is expected that further advances in understanding dynamic interactions of membrane proteins with the lipid bilayers can be achieved by combining experimental methods of fluorescence spectroscopy with Molecular Dynamics computer simulation. The integrated experi- mental and computational approaches will be instrumental in addressing fundamental questions related to the lipid-dependent regulation of protein functioning.

\section{Acknowledgments}

A.K acknowledges the Grant $0116 \mathrm{U} 000835$ from the Ministry of Education and Science of Ukraine. We are grateful to Drs. Mauricio Vargas-Uribe, Mykola V. Rodnin, Yevgen O. Posokhov, Chiranjib Ghatak, Sergiy Palchevskyy and Victor Vasquez-Montes for their contribution to the original studies described in this review.

\section{REFERENCES}

1. Young JA, Collier RJ. Anthrax toxin: receptor binding, internalization, pore formation, and translocation. Annu Rev Biochem. 2007;76:243-65.

2. Murphy JR. Mechanism of diphtheria toxin catalytic domain delivery to the eukaryotic cell cytosol and the cellular factors that directly participate in the process. Toxins (Basel). 2011;3(3):294-308.

3. Skehel JJ, Wiley DC. Receptor binding and membrane fusion in virus entry: the influenza hemagglutinin. Annu Rev Biochem. 2000;69:531-69.

4. Shamas-Din A, Kale J, Leber B, Andrews DW. Mechanisms of action of Bcl-2 family proteins. Cold Spring Harb Perspect Biol. 2013;5(4):a008714.

5. Bogner C, Leber B, Andrews DW. Apoptosis: embedded in membranes. Curr Opin Cell Biol. 2010;22(6):845-51.

6. Vargas-Uribe M, Rodnin MV, Ladokhin AS. Comparison of membrane insertion pathways of the apoptotic regulator $\mathrm{Bcl}-\mathrm{xL}$ and the diphtheria toxin translocation domain. Biochemistry. 2013;52(45):7901-9.

7. Moldoveanu T, Follis AV, Kriwacki RW, Green DR. Many players in BCL-2 family affairs. Trends Biochem Sci. 2014;39(3):101-11.

8. Luna-Vargas MP, ChipukJE. The deadly landscape of pro-apoptotic BCL-2 proteins in the outer mi- 
tochondrial membrane. FEBS J. 2016;283(14): 2676-89.

9. Ladokhin $A S$. pH-triggered conformational switching along the membrane insertion pathway of the diphtheria toxin T-domain. Toxins (Basel). 2013;5(8):1362-80.

10. Youle RJ, Strasser A. The BCL-2 protein family: opposing activities that mediate cell death. Nat Rev Mol Cell Biol. 2008;9(1):47-59.

11. Ladokhin $A S$. Fluorescence spectroscopy in thermodynamic and kinetic analysis of $\mathrm{pH}$-dependent membrane protein insertion. Methods Enzymol. 2009;466:19-42.

12. Ladokhin AS. Measuring membrane penetration with depth-dependent fluorescence quenching: distribution analysis is coming of age. Biochim Biophys Acta. 2014;1838(9):2289-95.

13. Ladokhin AS, Legmann R, Collier RJ, White SH. Reversible refolding of the diphtheria toxin T-domain on lipid membranes. Biochemistry. 2004;43(23):7451-8.

14. Palchevskyy SS, Posokhov YO, Olivier B, Popot JL, Pucci B, Ladokhin AS. Chaperoning of insertion of membrane proteins into lipid bilayers by hemifluorinated surfactants: application to diphtheria toxin. Biochemistry. 2006;45(8):2629-35.

15. Rodnin MV, Posokhov YO, Contino-Pépin C, Brettmann J, Kyrychenko A, Palchevskyy SS, Pucci B, Ladokhin AS. Interactions of fluorinated surfactants with diphtheria toxin T-domain: testing new media for studies of membrane proteins. Biophys $J$. 2008;94(11):4348-57.

16. Kyrychenko A, Posokhov YO, Rodnin MV, Ladokhin $A S$. Kinetic intermediate reveals staggered $\mathrm{pH}$-dependent transitions along the membrane insertion pathway of the diphtheria toxin T-domain. Biochemistry. 2009;48(32):7584-94.

17. Rodnin MV, Kyrychenko A, Kienker P, Sharma O, Posokhov YO, Collier RJ, Finkelstein A, Ladokhin AS. Conformational switching of the diphtheria toxin T domain. $J$ Mol Biol. 2010;402(1):1-7.

18. Rodnin MV, Kyrychenko A, Kienker P, Sharma $O$, Vargas-Uribe M, Collier RJ, Finkelstein A, Ladokhin AS. Replacement of C-terminal histidines uncouples membrane insertion and translocation in diphtheria toxin T-domain. Biophys $J$. 2011;101(10):L41-3.
19. Kyrychenko A, Rodnin MV, Vargas-Uribe M, Sharma SK, Durand G, Pucci B, Popot JL, Ladokhin AS. Folding of diphtheria toxin T-domain in the presence of amphipols and fluorinated surfactants: Toward thermodynamic measurements of membrane protein folding. Biochim Biophys Acta. 2012;1818(4):1006-12.

20. Kurnikov IV, Kyrychenko A, Flores-Canales JC, Rodnin MV, Simakov N, Vargas-Uribe M, Posokhov YO, Kurnikova M, Ladokhin AS. pH-triggered conformational switching of the diphtheria toxin T-domain: the roles of N-terminal histidines. $J \mathrm{Mol}$ Biol. 2013;425(15):2752-64.

21. Vargas-Uribe M, Rodnin MV, Kienker P, Finkelstein A, Ladokhin AS. Crucial role of $\mathrm{H} 322$ in folding of the diphtheria toxin T-domain into the openchannel state. Biochemistry. 2013;52(20):3457-63.

22. Flores-Canales JC, Vargas-Uribe M, Ladokhin AS, Kurnikova M. Membrane Association of the Diphtheria Toxin Translocation Domain Studied by Coarse-Grained Simulations and Experiment. J Membr Biol. 2015;248(3):529-43.

23. Ghatak C, Rodnin MV, Vargas-Uribe M, McCluskey AJ, Flores-Canales JC, Kurnikova M, Ladokhin AS. Role of acidic residues in helices TH8-TH9 in membrane interactions of the diphtheria toxin $\mathrm{T}$ domain. Toxins (Basel). 2015;7(4):1303-23.

24. Vargas-Uribe M, Rodnin MV, Öjemalm K, Holgado A, Kyrychenko A, Nilsson I, Posokhov YO, Makhatadze G, von Heijne G, Ladokhin AS. Thermodynamics of Membrane Insertion and Refolding of the Diphtheria Toxin T-Domain. J Membr Biol. 2015;248(3):383-94.

25. Walla PJ. Optical Properties of Biomolecules. Modern Biophysical Chemistry: Wiley-VCH Verlag GmbH \& Co. KGaA; 2014. p. 41-60.

26. Ladokhin AS, Jayasinghe S, White SH. How to measure and analyze tryptophan fluorescence in membranes properly, and why bother? Anal Biochem. 2000;285(2):235-45.

27. Demchenko AP, Duportail G, Oncul S, Klymchenko $A S$, Mély $Y$. Introduction to fluorescence probing of biological membranes. Methods Mol Biol. 2015;1232:19-43.

28. Demchenko AP, Mély Y, Duportail G, Klymchenko AS. Monitoring biophysical properties of lipid 
membranes by environment-sensitive fluorescent probes. Biophys J. 2009;96(9):3461-70. Review.

29. Ladokhin AS. Fluorescence Spectroscopy in Peptide and Protein Analysis. Encyclopedia of Analytical Chemistry: Applications of Instrumental Methods: John Wiley \& Sons, Ltd; 2000.

30. Kyrychenko A. Using fluorescence for studies of biological membranes: a review. Methods Appl Fluoresc. 2015;3(4):042003.

31. Reshetnyak YK, Segala M, Andreev OA, Engelman $D M$. A monomeric membrane peptide that lives in three worlds: in solution, attached to, and inserted across lipid bilayers. Biophys J. 2007;93(7):2363-72.

32. Kyrychenko A, Freites JA, He J, Tobias DJ, Wimley $W C$, Ladokhin $A S$. Structural plasticity in the topology of the membrane-interacting domain of HIV-1 gp41. Biophys J. 2014;106(3):610-20.

33. Kyrychenko A, Vasquez-Montes V, Ulmschnei$\operatorname{der} M B$, Ladokhin AS. Lipid headgroups modulate membrane insertion of pHLIP peptide. Biophys $J$. 2015;108(4):791-794.

34. Kaback $H R$, Wu J. What to do while awaiting crystals of a membrane transport protein and thereafter. Acc Chem Res. 1999; 32:805-813.

35. Wang J, Rosconi MP, London E. Topography of the hydrophilic helices of membrane-inserted diphtheria toxin T domain: TH1-TH3 as a hydrophilic tether. Biochemistry. 2006;45(26):8124-34.

36. Rosconi MP, London E. Topography of helices 5-7 in membrane-inserted diphtheria toxin $\mathrm{T}$ domain: identification and insertion boundaries of two hydrophobic sequences that do not form a stable transmembrane hairpin. J Biol Chem. 2002;277(19):16517-27.

37. Kyrychenko A, Posokhov YO, Vargas-Uribe M, Ghatak C, Rodnin MV, Ladokhin AS. Fluorescence Applications for Structural and Thermodynamic Studies of Membrane Protein Insertion. In: Geddes $C D$, editor. Reviews in Fluorescence 2016. Reviews in Fluorescence. Cham, Switzerland: Springer International Publishing; 2017:243-274.

38. Montagner C, Perier A, Pichard S, Vernier G, Ménez A, Gillet D, Forge V, Chenal A. Behavior of the $\mathrm{N}$-terminal helices of the diphtheria toxin $\mathrm{T}$ domain during the successive steps of membrane interaction. Biochemistry. 2007;46(7):1878-87.
39. Perier A, Chassaing A, Raffestin S, Pichard S, Masella M, Ménez A, Forge V, Chenal A, Gillet D. Concerted protonation of key histidines triggers membrane interaction of the diphtheria toxin $\mathrm{T}$ domain. J Biol Chem. 2007;282(33):24239-45.

40. May V, Kühn O. Excitation Energy Transfer. Charge and Energy Transfer Dynamics in Molecular Systems: Wiley-VCH Verlag $\mathrm{GmbH} \& \mathrm{Co} . \mathrm{KGaA}$; 2011:467-558.

41. Rusu L, Gambhir A, McLaughlin S, Rädler J. Fluorescence correlation spectroscopy studies of Peptide and protein binding to phospholipid vesicles. Biophys J. 2004;87(2):1044-53.

42. Rhoades E, Ramlall TF, Webb WW, Eliezer D. Quantification of alpha-synuclein binding to lipid vesicles using fluorescence correlation spectroscopy. Biophys J. 2006;90(12):4692-700.

43. Posokhov YO, Rodnin MV, Das SK, Pucci B, Ladokhin $A S$. FCS study of the thermodynamics of membrane protein insertion into the lipid bilayer chaperoned by fluorinated surfactants. Biophys J. 2008;95(8):L54-6.

44. Posokhov YO, Rodnin MV, Lu L, Ladokhin AS. Membrane insertion pathway of annexin B12: thermodynamic and kinetic characterization by fluorescence correlation spectroscopy and fluorescence quenching. Biochemistry. 2008;47(18):5078-87.

45. Melo AM, Prieto M, Coutinho A. Quantifying LipidProtein Interaction by Fluorescence Correlation Spectroscopy (FCS). In: Engelborghs Y, Visser $A J W G$, editors. Fluorescence Spectroscopy and Microscopy. Methods in Molecular Biology. 1076: Humana Press; 2014:575-95.

46. Nguyen TT, Swift JL, Cramb DT. Fluorescence Correlation Spectroscopy: The Measurement of Molecular Binding. In: Geddes CD, editor. Reviews in Fluorescence 2010. Reviews in Fluorescence. 2010: Springer New York; 2012. p. 45-66.

47. Schwille P, Korlach J, Webb WW. Fluorescence correlation spectroscopy with single-molecule sensitivity on cell and model membranes. Cytometry. 1999;36(3):176-82.

48. Hink MA. Fluorescence Correlation Spectroscopy. In: Verveer PJ, editor. Advanced Fluorescence Microscopy. Methods in Molecular Biology. 1251: Springer New York; 2015. p. 135-150. 
49. Lee H, Kim H. Membrane topology of transmembrane proteins: determinants and experimental tools. Biochem Biophys Res Commun. 2014; 453(2):268-76.

50. Heuck AP, Tweten RK, Johnson AE. Beta-barrel pore-forming toxins: intriguing dimorphic proteins. Biochemistry. 2001;40(31):9065-73.

51. Collier RJ, Young JA. Anthrax toxin. Annu Rev Cell Dev Biol. 2003;19:45-70.

52. Zakharov SD, Cramer WA. Colicin crystal structures: pathways and mechanisms for colicin insertion into membranes. Biochim Biophys Acta. 2002;1565(2): 333-46.

53. Zakharov SD, Cramer WA. On the mechanism and pathway of colicin import across the E. Coli outer membrane. Front Biosci. 2004;9:1311-7. Review.

54. Isas JM, Cartailler JP, Sokolov Y, Patel DR, Langen R, Luecke H, Hall JE, Haigler HT. Annexins V and XII insert into bilayers at mildly acidic $\mathrm{pH}$ and form ion channels. Biochemistry. 2000;39(11):3015-22.

55. Matsuzaki K, Murase O, Fujii N, Miyajima K. Translocation of a channel-forming antimicrobial peptide, magainin 2, across lipid bilayers by forming a pore. Biochemistry. 1995;34(19):6521-6.

56. Everett J, Zlotnick A, Tennyson J, Holloway PW. Fluorescence quenching of cytochrome b5 in vesicles with an asymmetric transbilayer distribution of brominated phosphatidylcholine. J Biol Chem. 1986;261(15):6725-9.

57. Wimley $W C$, White $S H$. Determining the membrane topology of peptides by fluorescence quenching. Biochemistry. 2000;39(1):161-70.

58. Ladokhin AS, White SH. Interfacial folding and membrane insertion of a designed helical peptide. Biochemistry. 2004;43(19):5782-91.

59. Ladokhin AS, Isas JM, Haigler HT, White SH. Determining the membrane topology of proteins: insertion pathway of a transmembrane helix of annexin 12. Biochemistry. 2002;41(46):13617-26.

60. Posokhov YO, Ladokhin AS. Lifetime fluorescence method for determining membrane topology of proteins. Anal Biochem. 2006;348(1):87-93.

61. Ladokhin AS. Distribution analysis of depth-dependent fluorescence quenching in membranes: A practical guide. In: Ludwig Brand MLJ, editor. Methods in enzymology. 278. New York: Academic Press; 1997. p. 462-473.

62. Ladokhin $A S$. Analysis of protein and peptide penetration into membranes by depth-dependent fluorescence quenching: theoretical considerations. Biophys J. 1999;76(2):946-55.

63. London E, Ladokhin AS. Measuring the depth of amino acid residues in membrane-inserted peptides by fluorescence quenching. In: Simon SA, McIntosh TJ, editors. Peptide-Lipid Interactions Current Topics in Membranes. 52. Amsterdam: Elsevier; 2002. p. $89-115$.

64. McIntosh TJ, Holloway PW. Determination of the depth of bromine atoms in bilayers formed from bromolipid probes. Biochemistry. 1987;26(6):1783-8.

65. Kyrychenko A, Ladokhin AS. Molecular dynamics simulations of depth distribution of spin-labeled phospholipids within lipid bilayer. J Phys Chem B. 2013;117(19):5875-85.

66. Kyrychenko A, Rodnin MV, Ladokhin AS. Calibration of Distribution Analysis of the Depth of Membrane Penetration Using Simulations and Depth-Dependent Fluorescence Quenching. J Membr Biol. 2015;248(3):583-94.

67. Kyrychenko A, Ladokhin AS. Refining membrane penetration by a combination of steady-state and time-resolved depth-dependent fluorescence quenching. Anal Biochem. 2014;446:19-21.

68. Kyrychenko A, Lim NM, Vasquez-Montes V, Rodnin MV, Freites JA, Nguyen LP, Tobias DJ, Mobley $D L$, Ladokhin AS. Refining Protein Penetration into the Lipid Bilayer Using Fluorescence Quenching and Molecular Dynamics Simulations: The Case of Diphtheria Toxin Translocation Domain. J Membr Biol. 2018;251(3):379-391.

69. Bennett MJ, Eisenberg D. Refined structure of monomelic diphtheria toxin at 2.3 A resolution. Protein Science. 1994; 3:1464-1475.

70. Flores-Canales JC, Kurnikova M. Microsecond Simulations of the Diphtheria Toxin Translocation Domain in Association with Anionic Lipid Bilayers. J Phys Chem B. 2015;119(36):12074-85.

71. Ladokhin AS, Vargas-Uribe M, Rodnin MV, Ghatak C, Sharma O. Cellular Entry of the Diphtheria Toxin Does Not Require the Formation of the 
Open-Channel State by Its Translocation Domain. Toxins (Basel). 2017;9(10). pii: E299.

\section{Флуоресцентні методи у дослідженні вбудовування мембранних білків}

О. В. Кириченко, О. С. Ладохін

Перехід розчинних білків до ліпідної мембрани та їх подальша перебудова $є$ фундаментальною ланкою у чисельних фізіологічних та біохімічних процесах. У цьому огляді нами наведено підсумки використання флуоресцентної спектроскопії у дослідженні посттрансляційного вбудовування мембранних білків до ліпідних бішарів. Розглянуто різноманітні методи, які використовують спектральні зонди, чутливі до зовнішнього оточення, ферстерівське резонансне перенесення енергії (ФРПЕ), флуоресцентну кореляційну спектроскопію (ФКС) та гасіння флуоресценції у встановленні структурних та кінетичних характеристик білок-ліпідної взаємодії. Наведено приклади застосування стаціонарного та часо-розділенного гасіння флуоресценції ліпідно-зв'язаними гасниками для дослідження занурення мембранних білків до ліпідного бішару. Наприкінці нами показано комбіноване використання різноманітних спектральних підходів для цілісного вивчення структурних, кінетичних та термодинамічних властивостей $\mathrm{pH}$-індукованої послідов-

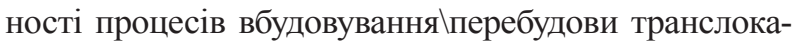
ційного домену дифтерійного токсину.

К л юч о в і с л о в а: флуоресцентна спектроскопія, флуоресцентна кореляційна спектроскопія, розподільчий аналіз глибинно-залежного гасіння, анексин, дифтерійний токсин, Bcl-xL

\section{Флуоресцентные методы в изучении встраивания мембранных белков}

А.В. Кириченко, А.С. Ладохин

Переход растворимых белков в липидную мембрану и их дальнейший рефолдинг является фундаментальной частью во многочисленных физиологических и биохимических процессах. У этом обзоре нами приведено обобщение применения флуоресцентной спектроскопии в изучении посттрансляционного встраивания мембранных белков в липидные бислои. Рассмотрены разнообразные методы, которые используют спектральные зонды, чувствительные к внешнему окружению, ферстеровский резонансный перенос энергии (ФРПЭ), флуоресцентную корреляционную спектроскопию (ФКС) и тушение флуоресценции для установления структурных и кинетических характеристик белок-липидного взаимодействия. Приведены примеры применения стационарного и время-разрешенного тушения флуоресценции липидно-связанными тушителями для изучения погружения мембранных белков в липидный бислой. Подводя итог нами показано комбинированное применение разнообразных спектральных подходов для целостного изучения структурных, кинетических и термодинамических свойств рН-индуцированной последовательности процессов встраивания \рефолдинга транслокационного домена дифтерийного токсина.

К л ю ч е в ы е с л о в а: флуоресцентна спектроскопия, флуоресцентна корреляционная спектроскопия, распределительный анализ глубинно-зависимого тушения, аннексин, дифтерийный токсин, Bcl-xL

Received 13.05.2018 